\title{
INVESTIGATING AND MODELLING EFFECTS OF CLIMATICALLY AND HYDROLOGICALLY INDICATORS ON THE URMIA LAKE COASTLINE CHANGES USING TIME SERIES ANALYSIS
}

\author{
M. Ahmadijamal ${ }^{\text {a }}$, M. Hasanlou ${ }^{\text {a* }}$ \\ a School of Surveying and Geospatial Engineering, College of Engineering, \\ University of Tehran, Tehran, Iran - (mitraahmadi, hasanlou@ut.ac.ir)
}

KEY WORDS: Modelling, Water level changes, Hydrological indicator, climatically indicator, Time series, Urmia Lake

\begin{abstract}
:
Study of hydrological parameters of lakes and examine the variation of water level to operate management on water resources are important. The purpose of this study is to investigate and model the Urmia Lake water level changes due to changes in climatically and hydrological indicators that affects in the process of level variation and area of this lake. For this purpose, Landsat satellite images, hydrological data, the daily precipitation, the daily surface evaporation and the daily discharge in total of the lake basin during the period of 2010-2016 have been used. Based on time-series analysis that is conducted on individual data independently with same procedure, to model variation of Urmia Lake level, we used polynomial regression technique and combined polynomial with periodic behavior. In the first scenario, we fit a multivariate linear polynomial to our datasets and determining RMSE, NRSME and R ${ }^{2}$ value. We found that fourth degree polynomial can better fit to our datasets with lowest RMSE value about $9 \mathrm{~cm}$. In the second scenario, we combine polynomial with periodic behavior for modeling. The second scenario has superiority comparing to the first one, by RMSE value about $3 \mathrm{~cm}$.
\end{abstract}

\section{INTRODUCTION}

Urmia Lake is one of the largest permanent lake in Middle East with a catchment area of $51,876 \mathrm{~km}^{2}$, comprising $3 \%$ of the country area and $7 \%$ of total surface water in Iran (Eimanifar \& Mohebbi, 2007). It is one of the largest salt lakes in the world in terms of surface area. This terminal lake is situated in the northwestern corner of Iran, near Turkey (Figure 1). It is located in the heart of two provinces of West Azerbaijan and East Azerbaijan at latitude $37^{\circ} 00^{\prime}$ to $38^{\circ} 12^{\prime} \mathrm{N}$, and longitude $44^{\circ} 40^{\prime}$ to $45^{\circ} 50^{\prime} \mathrm{E}$ (UNESCO, 2001). The Urmia Lake catchment has a population of about two million (West Azerbaijan Regional Water Authority, 2012a). The lake is divided into southern and northern parts by Martyr Kalantari causeway constructed across the lake for facilitation of communication between east (Tabriz City) and west (Urmia City) of the lake (Figure 2). Naturally most important factors that affects to level of lake water is climatically and hydrological factors. For example, changes in temperature and precipitation can be one of the most important climatical factors that considered in this study. Predict of climatic parameters and examine the future trends in the management of water resources is important (Wang et al. 2000). Urmia Lake is one of the 610 biosphere reserves in 117 countries recognized in 1976 under UNESCO's Man and the Biosphere (MAB) program (UNESCO, 2012). Unfortunately, during the last 17 years, there has been a rapid decline of the lake's water level (Figure 3).

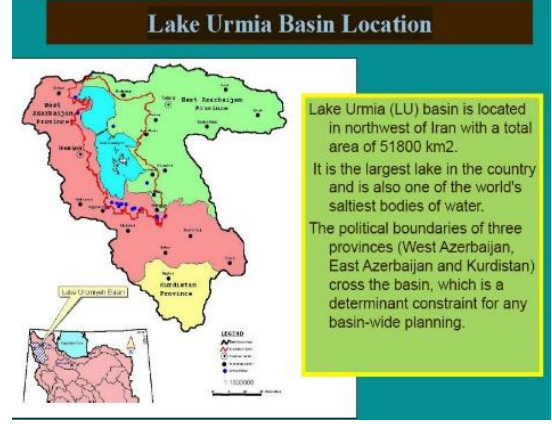

Figure 1. Lake Urmia drainage basin in the north west of Iran (Abbaspour et al. 2012)

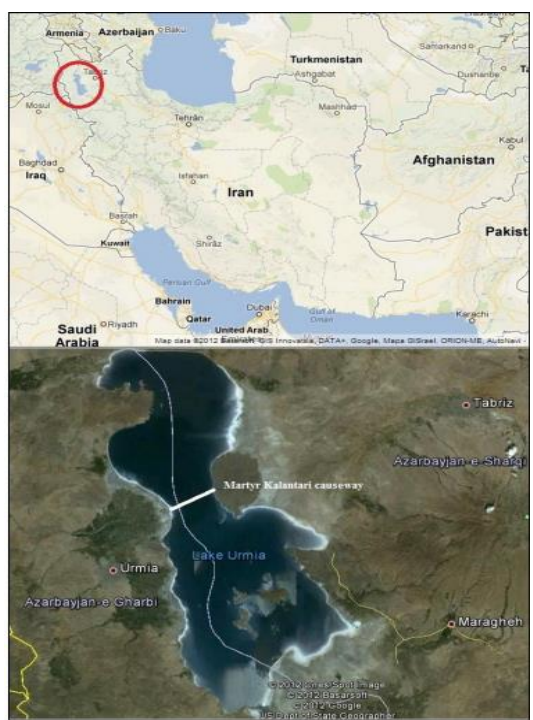

Figure 2. The map above shows the location of Urmia Lake in Iran. The other presents the Urmia Lake's general shape.

The bold line in the middle of the lake is the Martyr Kalantari causeway and the vertical line over the lake is the border between two provinces of East and West Azerbaijan (Google Earth, 2012)

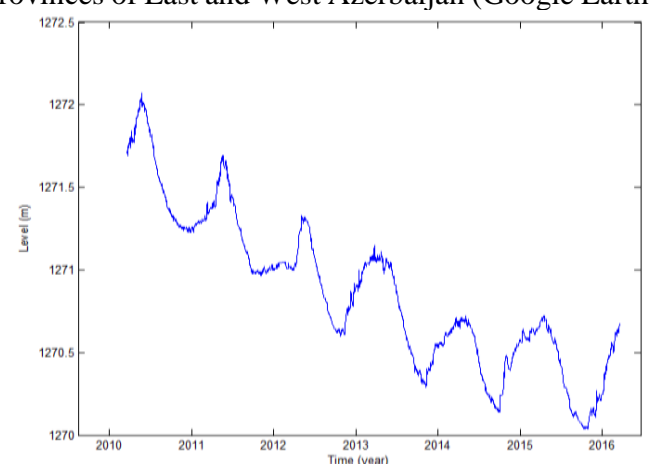

Figure 3. Urmia Lake's water level using various data (UNEP and GEAS, 2012)

* Corresponding author 
Rasuli et al (2008), the Lake level fluctuations with satellite images from 1976 and 2005 were examined. The researchers showed that variations of the Lake in the period of the time that has been studied, decreasing $23 \%$ of the level of the lake. In this study the main factors is not mentioned the lake is drying. Hesari and colleagues (2009), changes in the level of Lake Urmia and similarity behaviors with Caspian Sea level changes and Lake Van in Turkey's and climatic factors in area was examined. Studies based on monthly data for Lake water level in Lake Urmia during 1345-1388 showed clearly that the long-term trend is up to 6 meters. The results of existence of procedure, existence of the jump and the difference between mean and median from 1374 onwards and the process the lake. Level was not random and was confirmed at a significance level of $1 \%$. Lake Van behavior and changes in ground water levels have match conformity with the lake water level changes that was the existence of high pressure on the region's groundwater. Abdollahi and colleagues (2010) have noted that factors of declining in Urmia lake water can be divided into two groups of up grand and underground water factors. Surface factors have the greatest impact and they are the amount of atmospheric rainfall, changes in water flow and temperature change in the lake river Basin. Also underground factors such as changes in groundwater flow regime, due to changes in the lake bed of Lake causeway, salt accumulation and the broad masses and the incomparable masses in the bed of the lake and they are Effective in changing water level of lake

\section{STUDY AREA}

Urmia Lake is located in north-west Iran (37 $30^{\prime}, \mathrm{N}, 46^{\circ} 00^{\prime} \mathrm{E}$,), is the largest in Middle East and world's sixth largest saline lake with a surface area of approximately $4750-6000 \mathrm{~km}^{2}$ Extending $140 \mathrm{~km}$ and $85 \mathrm{~km}$ in south-north and east-west direction respectively during the historical period between 1965 and 2000 (Ghaheri, et al. 1999; Abbaspour et al. 2012; UNEP, 2012; Abatzopoulos et al 2006; Waiser and Robarts, 2009). Lake Urmia's drainage basin has an area of $51876 \mathrm{~km} 2$ including the lake. The lake's total annual inflow of $6.900 \mathrm{~km} 3$ has been estimated to be supplied from rivers by $4.9 \mathrm{~km}^{3}$, flood waters by $0.5 \mathrm{~km}^{3}$ and direct precipitation over the lake by $1.5 \mathrm{~km}^{3}$ (Ghaheri, et al. 1999; Eimanifar and Mohebbi, 2007). The main rivers of the LUDB are given in Table 1 . The only known output from the lake however, is direct evaporation from the lake surface (Hassanzadeh et al. 2011). The synoptic stations, climatological and precipitation that data from these stations were used to averaged variables basin show in Figure 4. Because of the lack of the other synoptic stations that study, the data was insufficient.

Table 1. Main river inflows to Lake Urmia (Ghaheri, et al. 1999)

\begin{tabular}{|c|c|c|c|}
\hline River & $\begin{array}{c}\text { Length } \\
(\mathrm{km})\end{array}$ & $\begin{array}{c}\text { Average flow } \\
\left(\mathrm{m}^{3} / \mathrm{s}\right)\end{array}$ & $\begin{array}{c}\text { Sub-basin area } \\
\left(\mathrm{km}^{2}\right)\end{array}$ \\
\hline Zarinneh Rood & 230 & 45.8 & 11897 \\
\hline Simineh Rood & 145 & 9.5 & 3656 \\
\hline Barandoozchai & 70 & 8.3 & 1318 \\
\hline Nazloochai & 85 & 7.87 & 2267 \\
\hline Mahabad Chai & 80 & 6.5 & 1528 \\
\hline Shahrichai & 70 & 5.33 & 720 \\
\hline Rowzehchai & 50 & 1.33 & 453 \\
\hline Godarchai & 100 & 0.34 & 2123 \\
\hline Zoolachai & 84 & - & 2090 \\
\hline
\end{tabular}

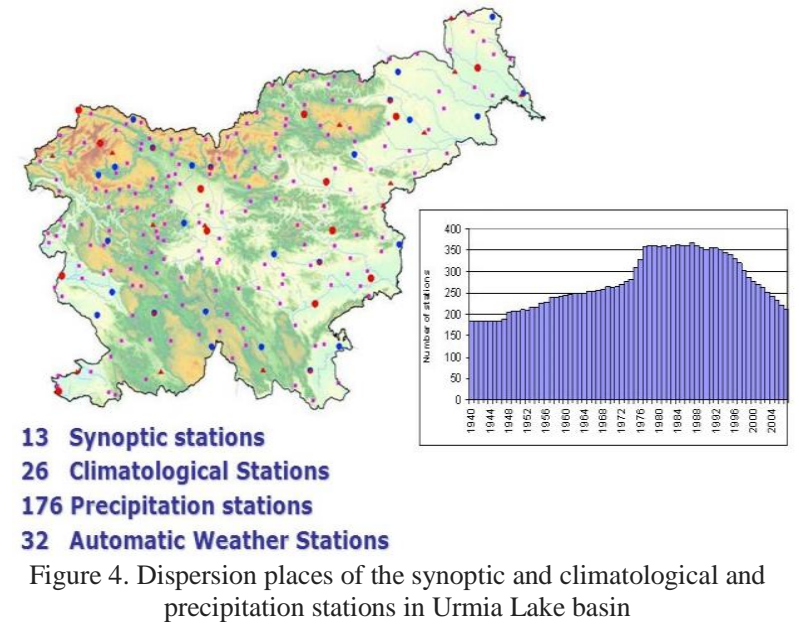

\section{MATERIALS AND METHODS}

In this study, Landsat satellite images from 2010 to 2016 years were used to examine changes the shoreline of Urmia Lake and also the software of ENVI4 and ERDAS were used to process images. The area of lake in each of the years was measurement from satellite images that determined the changes in the years of studies.

The main factors reducing the water level of the lake are (1) Average daily rainfall in total basin in the period of 2010-2016 using data from synoptic stations, rain-gauge and climatology studies in the basin. (2) Average daily temperatures in total basin in the period of 2010-2016 using data from synoptic stations, climatological studies in the basin. (3) Average daily potential evapotranspiration of total of the basin in the period of 2010-2016 using data from synoptic stations, climatological studies in the basin with cridal and tornjwhite methods. (4) Total of daily discharge of basin in the period of 2010-2016.

\section{RESERCH FINDING}

Analysis of satellite images shows that the lake water level changes in the scale of daily from the year of $(2010$ - 2016) is remarkable. Periodic changes in water level of the lake in Figure 3 is shown. According to available data from 2008 to 2016 and studies on a variety of modeling methods using time series analysis, the modeling is based on polynomial method and the method of least squares and the accuracy of $3 \mathrm{~cm}$ was achieved, also with due attention to the behavior periodic of the data evaporation and discharge of lake, we use combination polynomial method along with periodic behaviors. Their calculations are based on the method of least squares and accuracy was improved from $9 \mathrm{~cm}$ to $3 \mathrm{~cm}$. Trends of rainfall, evaporation, discharge and water level of the lake from 2008 to 2016 and on a daily basis are displayed in Figures 5, 6, 7, 8.

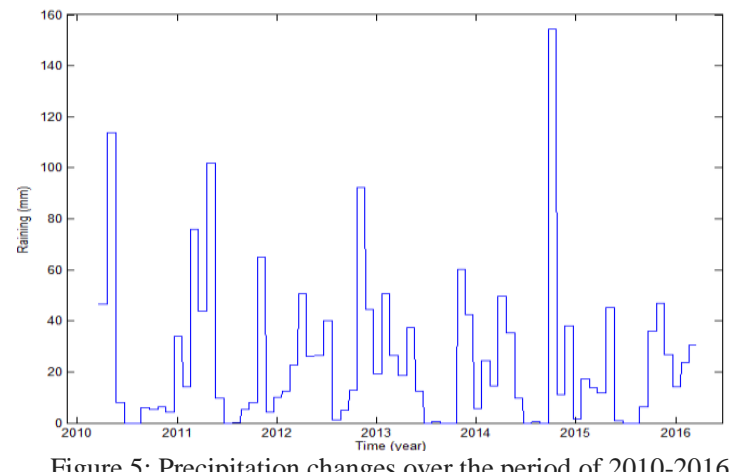

Figure 5: Precipitation changes over the period of 2010-2016 


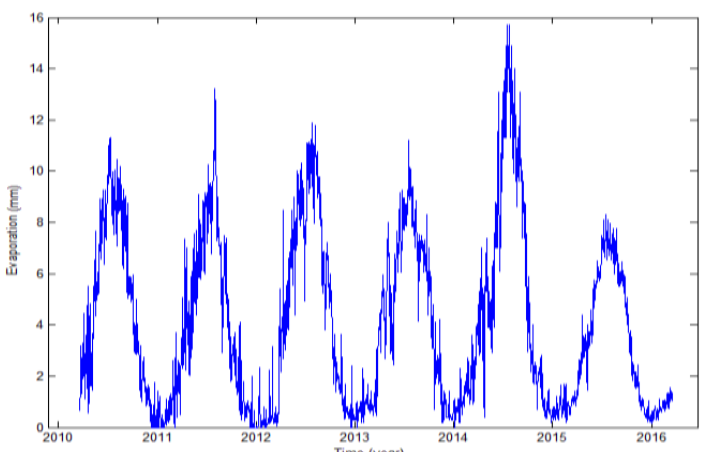

Figure 6: Evaporation changes over the period of 2010-2016

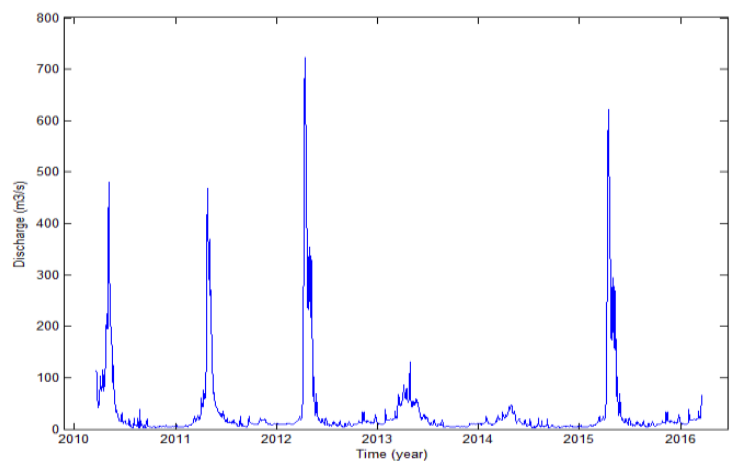

Figure 7: Discharge of changes over the period of 2010-2016

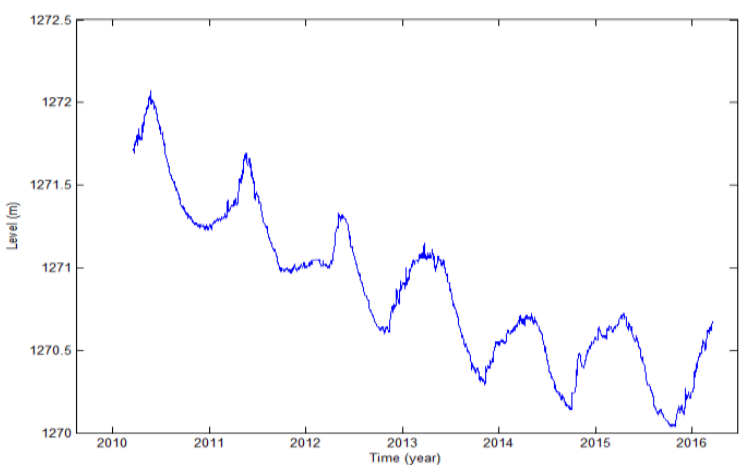

Figure 8: Level of water changes over the period of 2010-2016

In the following we use two scenarios for the lake water level time series determination.

\subsection{The first scenario}

The first degree of polynomial

$$
F(t, B, T, D)=a_{1}+a_{2} t+a_{3} B+a_{4} T+a_{5}
$$

The second degree of polynomial

$$
\begin{aligned}
F(t, B, T, D)=a_{1}+ & a_{2} t+a_{3} B+a_{4} T+a_{5} D+a_{6} t^{2} \\
& +a_{7} B^{2}+a_{8} T^{2}+a_{9} D^{2}+a_{10} t B \\
& +a_{11} t T+a_{12} t D+a_{13} B T \\
& +a_{14} B D+a_{15} T D
\end{aligned}
$$

The third degree of polynomial

$$
\begin{aligned}
F(t, B, T, D)=a_{1}+ & a_{2} t+a_{3} B+a_{4} T+a_{5} D+a_{6} t^{2} \\
& +a_{7} B^{2}+a_{8} T^{2}+a_{9} D^{2} \\
& +a_{10} t B+a_{11} t T+a_{12} t D \\
& +a_{13} B T+a_{14} B D+a_{15} T D \\
& +\cdots+a_{33} t B D+a_{34} t T D \\
& +a_{35} B T D
\end{aligned}
$$

The fourth degree of polynomial

$$
\begin{aligned}
F(t, B, T, D)=a_{1}+ & a_{2} t+a_{3} B+a_{4} T+a_{5} D \\
& +a_{6} t^{2}+a_{7} B^{2}+a_{8} T^{2} \\
& +a_{9} D^{2}+a_{10} t B+a_{11} t T \\
& +a_{12} t D+a_{13} B T+a_{14} B D \\
& +a_{15} T D+a_{16} t^{3}+a_{17} B^{3} \\
& +a_{18} T^{3}+a_{19} D^{3}+\cdots \\
& +a_{70} t B T D
\end{aligned}
$$

The result of fitting four before equations are shown in Figures 9 to 12 .

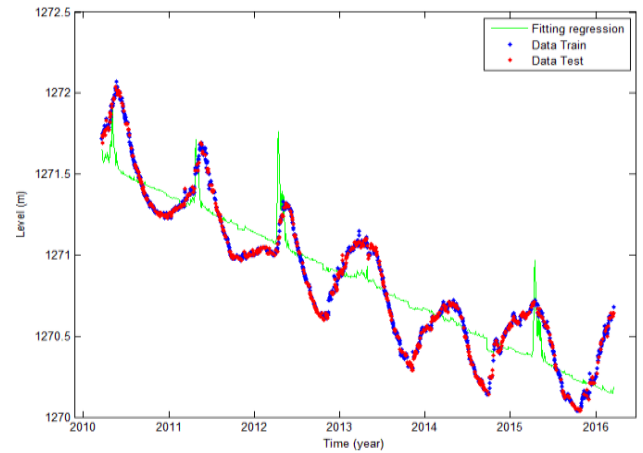

Figure 9: The regression graph of $1^{\text {st }}$ degree of polynomial

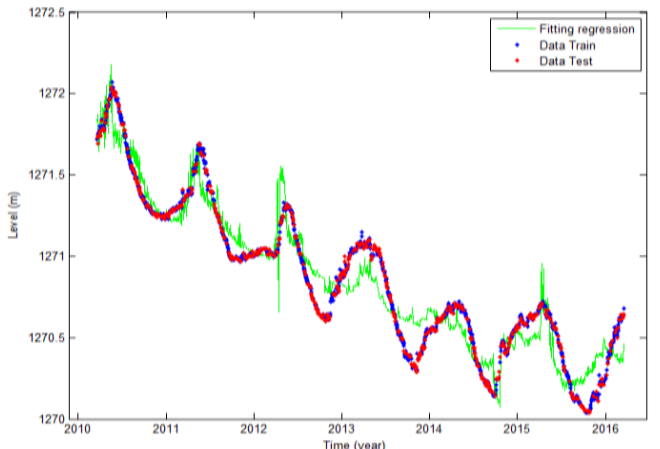

Figure 10: The regression graph of $2^{\text {nd }}$ degree of polynomial

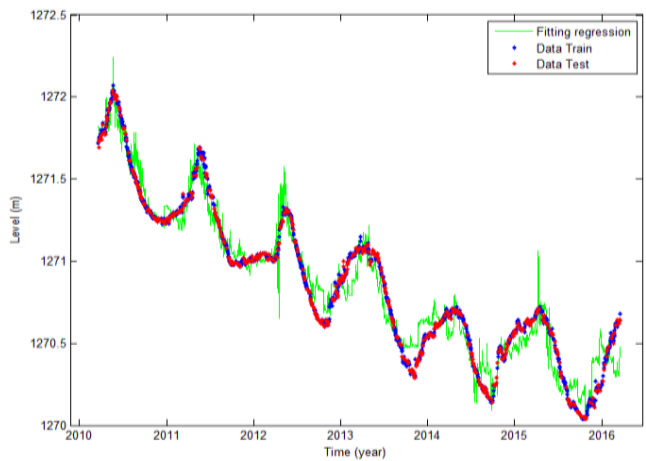

Figure 11: The regression graph of $3^{\text {rd }}$ degree of polynomial

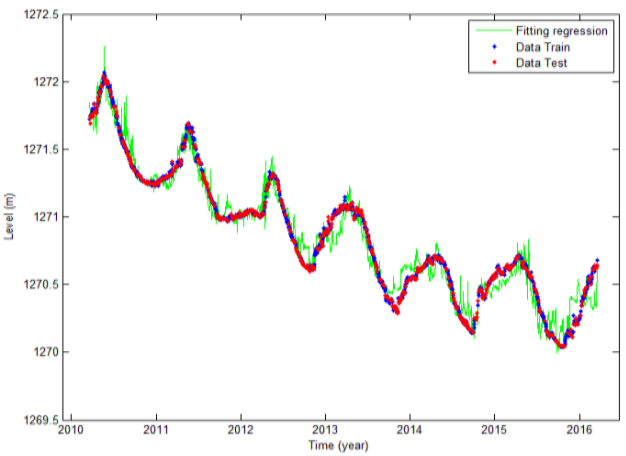

Figure 12: The regression graph of $4^{\text {th }}$ degree of polynomial 
For assessing the accuracy of two scenarios, we used the index of root mean square error (RMSE), normalized root mean square error (NRMSE) and the coefficient of determination $\left(\mathrm{R}^{2}\right)$ in accordance of 5 to 7.

$$
\begin{gathered}
\text { RMSE }=\sqrt{\frac{\sum_{i=1}^{n}\left(x_{p}-x_{o}\right)^{2}}{n}} \\
\text { NRMSE }=\frac{R M S E}{x_{o b s, \text { max }}-x_{o b s, \text { min }}} \\
\mathrm{R}^{2}=\frac{S S R}{S S T}=1-\frac{S S E}{S S T} \\
\mathrm{SSE}=\sum_{i=1}^{n}\left(x_{p}-x_{o}\right)^{2} \\
\mathrm{SST}=\sum_{i=1}^{n}\left(x_{i}-x_{\text {mean }}\right)^{2}
\end{gathered}
$$

Where $X p$ is estimated parameters, $X o$ is observational parameters and $\mathrm{n}$ is the number of observations. By using the parameters between the estimated values and the best model observational values, the best model was selected. The values of these parameters for these four methods were calculated and is shown in Table2.

Table 2: Estimate accuracy of Lake water level model by using of time, balance model using time, monthly average of rainfall, evaporation and discharge of lake (polynomial)

\begin{tabular}{|c|c|c|c|c|c|c|}
\hline \multirow{2}{*}{$\begin{array}{c}\text { degree of } \\
\text { polynomial }\end{array}$} & \multicolumn{2}{|c|}{ RMSE } & \multicolumn{2}{c|}{ NRMSE } & \multicolumn{2}{|c|}{$\mathrm{R}^{2}$} \\
\cline { 2 - 7 } & Train & Test & Train & Test & Train & Test \\
\hline $1^{\text {st }}$ & 0.191 & 0.196 & 0.094 & 0.098 & 0.831 & 0.816 \\
\hline $2^{\text {nd }}$ & 0.138 & 0.141 & 0.068 & 0.070 & 0.912 & 0.905 \\
\hline $3^{\text {rd }}$ & 0.110 & 0.114 & 0.054 & 0.057 & 0.943 & 0.938 \\
\hline $4^{\text {th }}$ & 0.098 & 0.100 & 0.048 & 0.050 & 0.955 & 0.952 \\
\hline
\end{tabular}

\subsection{The second scenario}

In the second scenario for preparing the model of Lake water level, we used combination of polynomial along with the periodic behavior method that used from sum of polynomial of periodic signal in the time series. In the next step, the same way as the first method $30 \%$ of the data did not enter to the equation and the remaining $70 \%$ of data was used to calculations and then after obtaining the results, we used the remainder data and compared the results.

The first degree of polynomial+periodic behavior

$$
\begin{aligned}
F(t, B, T, D)=a_{1}+ & a_{2} t+a_{3} B+a_{4} T+a_{5} D \\
& +b_{1} \sin (\pi t)+b_{2} \cos (\pi t) \\
& +b_{3} \sin (2 \pi t)+b_{4} \cos (2 \pi t) \\
& +b_{5} \sin (4 \pi t)+b_{6} \cos (4 \pi t) \\
& +\cdots+b_{25} \sin (24 \pi t) \\
& +b_{26} \cos (24 \pi t)
\end{aligned}
$$

The second degree of polynomial+periodic behavior

$F(t, B, T, D)=a_{1}+a_{2} t+a_{3} B+a_{4} T+a_{5} D+a_{6} t^{2}$

$$
\begin{aligned}
& +a_{7} B^{2}+a_{8} T^{2}+a_{9} D^{2} \\
& +a_{10} t B+a_{11} t T+a_{12} t D \\
& +a_{13} B T+a_{14} B D+a_{15} T D \\
& +b_{1} \sin (\pi t)+b_{2} \cos (\pi t) \\
& +b_{3} \sin (2 \pi t)+b_{4} \cos (2 \pi t) \\
& +\cdots+b_{25} \sin (24 \pi t) \\
& +b_{26} \cos (24 \pi t)
\end{aligned}
$$

The third degree of polynomial+periodic behavior

$$
\begin{aligned}
F(t, B, T, D)=a_{1}+ & a_{2} t+a_{3} B+a_{4} T+a_{5} D \\
& +a_{6} t^{2}+a_{7} B^{2}+a_{8} T^{2} \\
& +a_{9} D^{2}+a_{10} t B+a_{11} t T \\
& +a_{12} t D+a_{13} B T+a_{14} B D \\
& +a_{15} T D+b_{1} \sin (\pi t) \\
& +b_{2} \cos (\pi t)+b_{3} \sin (2 \pi t) \\
& +b_{4} \cos (2 \pi t)+\cdots \\
& +b_{23} \sin (22 \pi t) \\
& +b_{24} \cos (22 \pi t) \\
& +b_{25} \sin (24 \pi t) \\
& +b_{26} \cos (24 \pi t)
\end{aligned}
$$

The forth degree of polynomial+periodic behavior

$$
\begin{aligned}
F(t, B, T, D)=a_{1}+ & a_{2} t+a_{3} B+a_{4} T+a_{5} D \\
& +a_{6} t^{2}+a_{7} B^{2}+a_{8} T^{2} \\
& +a_{9} D^{2}+a_{16} t^{3}+a_{17} B^{3} \\
& +a_{18} T^{3}+a_{19} D^{3}+\cdots \\
& +a_{69} B T D^{2}+a_{70} t B T D \\
& +b_{1} \sin (\pi t)+b_{2} \cos (\pi t) \\
& +b_{3} \sin (2 \pi t)+b_{4} \cos (2 \pi t) \\
& +b_{5} \sin (4 \pi t)+\cdots \\
& +b_{25} \sin (24 \pi t) \\
& +b_{26} \cos (24 \pi t)
\end{aligned}
$$

Results of fitting of formula 8 through 11 respectively are shown in Figures 13 to 16.

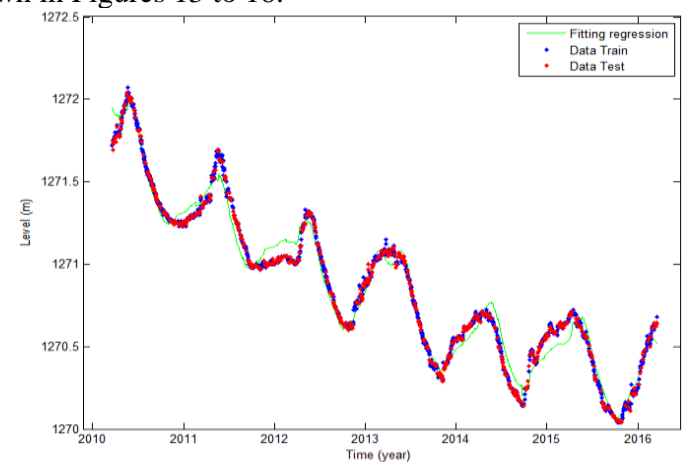

Figure 13: The regression graph of $1^{\text {st }}$ degree polynomial +

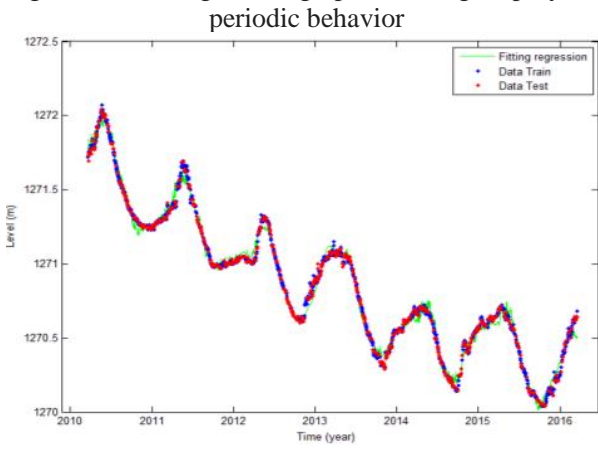

Figure 14: The regression graph of $2^{\text {nd }}$ degree polynomial +

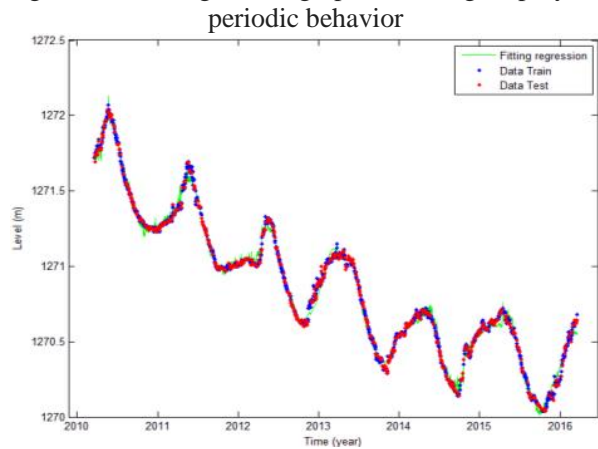

Figure 15: The regression graph of $3^{\text {rd }}$ degree polynomial +

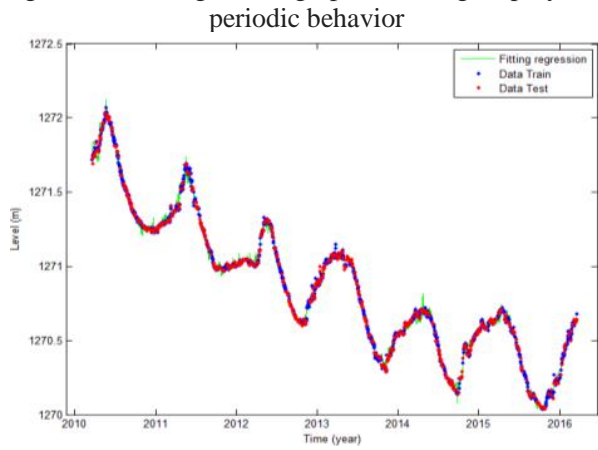

Figure 18: The regression graph of $4^{\text {th }}$ degree polynomial + periodic behavior 
The values of statistical parameters for second scenario were shown in Table3.

Table 3: Estimate accuracy of Lake water level model by using of time, balance model using time, monthly average of rainfall, evaporation and discharge of lake (polynomial +periodic behavior)

\begin{tabular}{|c|c|c|c|c|c|c|}
\hline $\begin{array}{c}\text { degree of } \\
\text { polynomial } \\
+\begin{array}{c}\text { periodic } \\
\text { behavior }\end{array}\end{array}$ & \multicolumn{2}{|c|}{ RMSE } & \multicolumn{2}{|c|}{ NRMSE } & \multicolumn{2}{|c|}{$\mathrm{R}^{2}$} \\
\cline { 2 - 7 } & Train & Test & Train & Test & Train & Test \\
\hline $1^{\text {st }}$ & 0.07 & 0.07 & 0.03 & 0.03 & 0.97 & 0.97 \\
\hline $2^{\text {nd }}$ & 0.04 & 0.043 & 0.02 & 0.02 & 0.99 & 0.99 \\
\hline $3^{\text {rd }}$ & 0.03 & 0.03 & 0.01 & 0.01 & 0.99 & 0.99 \\
\hline $4^{\text {th }}$ & 0.02 & 0.02 & 0.01 & 0.01 & 0.99 & 0.99 \\
\hline
\end{tabular}

\section{CONCLUSION}

In order to increase the accuracy of estimate results of the time series in different applications, approximation and the correct analysis is the essential. In this study, a method called multivariate analysis, for modeling the lake level changes due to changing hydrological parameters affecting it were presented. Since we already did not know the integrity of our data in real time series, so to ensure that the method was correctness, we render the number of data and used remaining observations data on annual period and was used during the period of 1 years and once again we used multivariate analysis and at the next time we used combination of multivariate analysis along with periodic behavior. At the first multivariate analysis was used to modeling the changes of Lake water level and results were presented separately for the four time series. At the next time we used the combination method of multivariate analysis along with periodic behaviour on observation data. The results of the calculations show that the use of general two models of multivariate analysis and combined with periodic behavior in all conditions listed, using combination multivariate analysis with periodic behavior was raised the accuracy of modeling. In the multivariate analysis method, accuracy of modeling was accomplishment about $9 \mathrm{~cm}$ and with combination of multivariate analysis and periodic behavior method, the accuracy was raised to $3 \mathrm{~cm}$. The main objective of this study was to test multivariate analysis with periodic behavior according to the results, the test was successful and the results have been more complete.

\section{REFERENCES}

Abbaspour, M. \& Nazaridoust, A., 2007. Determination of environmental water requirement of Lake Urmia, Iran: an ecological approach. International Journal of Environmental Studies, Volume 64 (2), pp. 161-169.

Astushi, U., Masaki T. and Yoshio I., 2004. Lake - level changes during the past 100000 Years at Lake Baikal, Southern Siberian, Quaternary research, and 62: 214-222.

Beatly, T. Brower, DJ. \& Schwab AK., 2002. An introduction to coastal zone management. Second edition, Island Press: 1-329.

Carmen, CJ. Herrero, MA. Casterad, 2005. Landsat monitoring of playa-lake in the Spanish Monegros desert, Journal of Arid Environments 63:497-516.

Dolan, R., Fenster, M.S., Holme, S.J., 1991. Temporal analysis of shoreline recession and accretion. Journal of Coast research 7(3): 723-744.

Douglas, B.C., Crowell, M., 2000. Long- term shoreline position prediction and error propagation. Journal of Coast research 16(1): 145-152.

Emamifar, A., \& Mohebbi, F., 2007. Urmia Lake (Northwest Iran): a brief review. Saline Systems, 3(5).
Ebdon, D., 1985. Statistics in Geography: a practical approach, second edition, BlackwellPublishing: 1-230.

Ecersin, E., Ormeci, C., 2010. Evaluates climate change effects on water and salt resources in salt lake, Turkey using multitemporal SPOT imagery, Environ Monit Assess, 163: 361368.

Google Earth, 2012. [Online] Urmia Lake $37^{\circ} 00^{\prime}$ to $38^{\circ} 12^{\prime} \mathrm{N}$, $44^{\circ} 40^{\prime}$ to $45^{\circ} 50^{\prime} \mathrm{E}$ Available at: http://maps.google.se/maps?hl=sv\&bav=on.2,or.r_gc.r_pw.r_qf. \&biw $=1366 \&$ bih $=673 \&$ wrapid

$=$ tlif $134902120274310 \& q=$ urmia + lake $\& u m=1 \& i e=U T F-$

8\&hq=\&hnear=0x401ab691484226e9:0xa3bcb751ad9dec7a,La $\mathrm{ke}+\mathrm{Urmia} \& \mathrm{gl}=\mathrm{se} \& \mathrm{sa}=\mathrm{X} \& \mathrm{ei}=\mathrm{IG}$

5oUM_AN7SK4gSkpoCoCA\&ved=0CD0Q8gEwAw

[Accessed 20 September 2012].

Hassanzandeh, E., Zarghami, M. \& Hassanzadeh, Y., 2011. Determining the Main Factors in Declining the Urmia Lake Level by Using Dynamics Modelling. Water Resources Management, 26(1), pp.129-145, doi: 10.1007/s11269-011-9909-8.

Ghaheri, M., Baghal-Vayjooee, M.H. \& Naziri, J., 1999. Lake Urmia, Iran: A summary Review. International Journal of Salt Lake Research, 8, pp.19-22

Hesari, B., Tayefeh, N.N. 2010. Investigation of Urmia Lake level changes and its relation with Caspian Sea level changes and Van Lakes in Turkey and area climate factors, the secondary of national congress environmental crisis of Urmia Lakes, Naghadeh Payam Noor University: 1-14.

Johnson, RA. \& Wichern Dean, W., 1988. Applied multivariate statistical analysis, Prentice Hall International Inc.

Liu, H. Jezek, KC. 2004. Automated of coastline imagery by integrating canny edgy detection and locally adaptive thresholding methods. International journal remote Sensing 25(5):937-958.

Rasuli, AA., Abasian, Sh., Jahanbakhsh, S., 2008. Monitoring of Urmia Lake level fluctuation by multispectral and multi temporal satellite images process, Modarres Journal of human sciences, 2: 53-71

UNESCO, 2001. MAB Biosphere Reserves Directory, Lake Oromeeh. [Online] Available at: http://www.unesco.org/mabdb/br/brdir/directory/biores.asp?cod e=IRA+07\&mode $=$ all [Accessed 18 September 2012].

UNESCO, 2012. Global list of Biosphere reserves. [Online] Available at: http://www.unesco.org/new/fileadmin/MULTIMEDIA/HQ/SC/ pdf/sc_mab_BR2012.pdf [Accessed 18 September 2012].

West Azerbaijan Regional Water Authority, 2012a. [Online] Available at: http://www.agrw.ir/Farsi/AreaF.asp?Id=3 [Accessed 16 September 2012].

West Azerbaijan Regional Water Authority, 2012b. [Online] Available at: http://www.agrw.ir/Farsi/UsageF.asp?Id=5 [Accessed 29 September 2012].

Waiser, M.J. and Robarts R.D., 2009. Saline Inland Waters, In Encyclopedia of Inland Waters, edited by Gene E. Likens, Academic Press, Oxford, Pages 634-644.

Comperhensive management plan for the Lake, 2010. Developed in collaboration with government agencies, environmental organizations and local communities: 1-75. 